\title{
建築物の言語描写における面の多義性 POLYSEMY OF PLANE IN TEXT DESCRIPTION OF BUILDINGS
}

\author{
北川啓介*，黒田祐五**，鳥居智之*** \\ Keisuke KITAGAWA, Yugo KURODA and Tomoyuki TORII
}

\begin{abstract}
Plane is a concept which has been dealt with as a basic constituent particularly in architecture. Plane is, in space, created on the surface based on the features and conditions of phenomenona. Plane also exists mutually involved in those various phenomena on the surface. Architects image architectural space and characterize the space by using the concept of plane. From these backgrounds, a word: plane, which has been described for various meanings of words in terms of text description by architects. In this research, we analyzed text description of buildings by architects and finally define 19 types of polysemy of plane and their relationship.
\end{abstract}

Keywords : Polysemy, Plane, Text Description, Adjectival Term, Verbal Term 多義性，面，言語描写，形容句，作用句

\section{1.はじめに}

一般的に，面は建築物をはじめとする物の外側の部分や広がりを 指し，事物を捉える際に，その多くを視覚的情報に依存する我々に とって，それがもつ「もののおもて」や「ものの示す方向」といっ た意味において, 密接な係わりもつ言葉である。J.J.Gibson は著書で ある『生態学的知覚論』1) において, 人が知覚できる実体のあるもの を面（surface），人の認識によって捉えられる実体のないものを平面 (plane) と定義している。実体のないイメージから, 実体としての建 築を創造する建築家にとって，この $2 つ の$ 概念をもつ面という言葉 は, 建築領域の中で根幹となる要素であるといえる。

空間は様々な事象により成立している。事象の性質や状態の違い により境目が生じ，そこに面が生まれる。面は，建築物における構 成に加え, 人や物, 自然などの事物, 光や音, 人の活動などの現象 の性質や状態をもち, そこに存在する様々な事象と相互に係わり合っ て存在している。建築家はそれら空間における諸要素に対して, 面 の概念を用いることで，空間を様々に性格づけてきた。また，特に 建築家の設計活動の中で多分にみられる，空間を二次元に変換する という行為は，計画する空間に面の概念と強い結びつきをもたらし ているといえる。そして，二次元から新たに空間が生まれる過程に
おいて建築家独自の面の概念が形成され，出来上がる空間はいわば 面の概念の集積であるといえる。面に多様な概念が生まれる要因は, このような建築の創作過程からも伺える。このような背景により， 現在までに面は，建築家による様々な解釈の対象としてその概念の 幅を広げてきた言葉であることは自明であり，建築家の言説におい ても必然的に，多様な言語描写がされてきた言葉であるといえる。

以上より，建築家独自の認知・解勫をもとに建築空間における面 の概念には，その性質や効果の担う役割の差異により多様な意味が 形成されてきたといえる。そのため, 建築家が面の概念を紐解くこ とで生じた多義性について論考することで得られる成果は, 建築家 が思考し，創作してきた建築空間についての言語描写を読み解くた め，面の概念に対する思考・解釈の枠組みの一端を明らかにすると ともに，面に対する建築家の論考を総合的な知見から再評価する上 でも重要な指標になると考える。また，本稿ではこれまで筆者らが 進めてきた建築分野における言葉の「多義性」2〜4) の研究を通して, それらの初源的な言葉における意味の枠組みに対する知見を蓄積し ていくことで，建築計画における普遍的な思想や通史的な建築のメ カニズムを捉える一連の研究の一環として，建築物の言語描写にお ける面の多義性について明らかにすることを目的とする。

\footnotetext{
* 名古屋工業大学大学院つくり領域 准教授・博士(工学) Assoc. Prof., Tsukuri College, Graduate School of Engineering, Nagoya Institute of

** 名古屋工業大学大学院工学研究科 博士後期課程 $\cdot$ 修士 (芸術)

*** 名古屋工業大学大学院工学研究科 博士後期課程 $\cdot$ 修士 (工学)
} 


\section{2. 既往の研究}

文学作品の読み取りから，空間描写の解釈を明らかにした研究と して，建築分野以外のものである文学作品に着目することで，建築 の概念を間接的に取り上げ，空間構成を考察することで，建築が生 じてくる基盤である深層の意味を表出する働きをなす成り立ちを捉 えている徐貴淑らによる研究 5) が挙げられる。建築家の言説を扱う 点, 言語描写における修飾表現に着目し, 分析を行う点については, 既往研究と同じ立場をとっている。しかし，語句を特定し，その語 句を意味付ける修飾句としての形容句，言語描写において作用的性 質のもつ文節としての作用句という二つの要素から, 語句同士の客 観的な相関として分析を行っている点において既往と異なる。

また，空間の図式の研究として，空間構成における特定の体系が 人に空間を認知させることに着目し，場所の概念，位置関係の規定 から空間図式をモデル化した横山勝樹らによる研究 ${ }^{6}$ が挙げられる。 本稿では，あくまで言語描写から面の概念を捉えることを目的とし ており, 実空間を対象に, 図面や写真から空間構成を分析する研究 とも異なる立場をとる。

\section{3. 研究の流れ}

以下に研究の流れを段階的に示す。

1）本稿では, 物の外郭をなす角のないひろがり, 二次元の連続体, 物の外側・おもて側, 物の外部の平らな広がり, 外面または表面, 立体とその周囲の空間との境, 顔に似せて作ったもの, 及び空間に 存在する建築物や自然などの具象的事物から概念的なものなどを 含む抽象的事象の様々な事象との関わりについて描写された面を <面 > 注1) とする。

2)『新建築』7に掲載された建築家の作品に対する解説文の中で建 築空間と係わるく面＞についての記述を研究対象とする（図 1 )。

\begin{tabular}{|c|c|c|c|}
\hline 新建築 1992 年 5 月号 & \multicolumn{2}{|c|}{ 抽出語句 } & 分類 \\
\hline 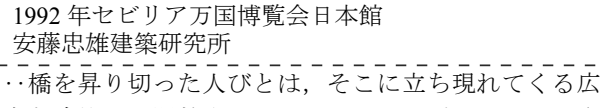 & 面 & 膜 & 【膜】 \\
\hline 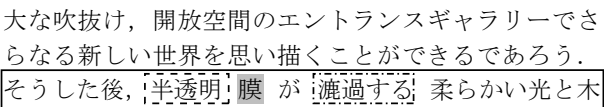 & 句 & 平透明! & 〔明度〕 \\
\hline 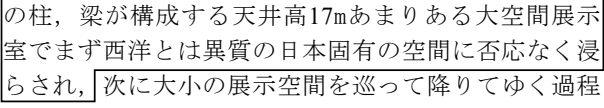 & 句 & 濾過与る & [抽出］ \\
\hline $\begin{array}{l}\text { で人は緊張感を高めながら日本の歴史を深さとして体 } \\
\text { 験していくはず. }\end{array}$ & & 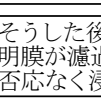 & 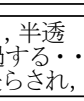 \\
\hline
\end{tabular}

図 $1<$ 面 $>$ の種類・形容句・作用句の抽出例

3）研究対象から，空間における＜面＞として描写された語を＜面 $>$ の種類として抽出する。研究対象内において $<$ 面 $>$ の種類に対し て，性質・状態を表現する形容的な分節を形容句，動作・作用を表 現する作用的な分節を作用句としてそれぞれ抽出する注2)。例えば， 文中において形容詞などで表現されるものは形容句とし，主述の関 係など作用的性質のある文節や詳解・限定を与え，または受ける作 用的性質のある文節を作用句とする。本稿における形容句・作用句 とは, 研究対象内で記述され，＜面>と組み合わさることで，＜面> の一側面としての意味を決定づける要素である。

4）研究対象内の前後の文脈を判断基準としながら，その語句がも つ意味に応じて抽出したそれぞれの語句のカテゴリー分けを行い,
<面 >の種類と形容句，〈面>の種類と作用句においてそれぞれク ロス集計を行う。カテゴリーの設定方法については，個人による独 断や恣意を避け，妥当な分類基準を設定できるよう，複数の著者に よる合議制の親和図法 ${ }^{3)}$ を採用するものとする。

5）並列化した語句を統計処理することで，見えにくくなった多数 の語句の相互関係を総体的に把握するために，＜面>の種類と形 容句，＜面>の種類と作用句においてそれぞれコレスポンデンス 分析 ${ }^{3)}$ を行い, 分類同士の対応関係を整理する。また，本研究に おけるコレスポンデンス分析は，得られた散布図から読み取れる要 素同士の結びつきに着目することに加え，その散布状況からく面 $>$ の概念実体を傾向として得るための解析と位置づける。

6）5）で得られた<面>の形容句，作用句の特徵の組み合わせを 基にすべての資料を相互に比較検討し，〈面＞がもつ側面を相対 的に位置づけることで，＜面＞の多義性としての類型を導出する。 また, 得られた類型についてそれぞれ考察を行い, 結論を導く。

\section{4. 研究対象}

本稿では，既報の「多義性」の研究と同様に，『新建築』を研究資 料として選定した。対象期間は執筆者の作品に対する解説文の文責 が明確であることから 1950 年から 2009 年までとしている（表 1 ）。 そして, 研究資料に掲載された建築家自身の作品に対寸る解説文の 中で，建築空間と係わるく面>について記述された 1644 事例を本稿 における研究対象とする。

表 1 年別研究対象数

\begin{tabular}{|c|c|c|c|}
\hline 年 & 対象数 & 年 & 対象数 \\
\hline $1950 \sim 1954$ & 49 & $1980 \sim 1984$ & 194 \\
\hline $1955 \sim 1959$ & 53 & $1985 \sim 1989$ & 176 \\
\hline $1960 \sim 1964$ & 40 & $1990 \sim 1994$ & 136 \\
\hline $1965 \sim 1969$ & 72 & $1995 \sim 1999$ & 214 \\
\hline $1970 \sim 1974$ & 101 & $2000 \sim 2004$ & 257 \\
\hline $1975 \sim 1979$ & 120 & $2005 \sim 2009$ & 232 \\
\hline & 計 & 1644 \\
\cline { 2 - 4 } & &
\end{tabular}

\section{5. 形容句と<面 >の種類のコレスポンデンス分析}

抽出した<面 >の種類を分類する（表 2 ）。これにより，日本語の 表記における漢字表現・平仮名表現・送り仮名の差異を解消し, 空 間内に描写された<面 >の種類を考察する。なお，本稿では分類の 過程において＜面＞の意味合いの傾向から大分類をしている。ただ し，単に面と描写された語句については，それ自体が多くの意味合 いを含むものであるため，大分類の対象としていない。

同じく抽出した<面>の形容句を分類する（表 3 ）。形容句は言語 描写内において, <面>の感覚や感情, 状況や物理的側面を表現す るはたらきをもつ形容的な修飾句であり，〈面>の種類と組み合わ さることで言語描写内での<面 >の一側面を意味づける要素である。 抽出した形容句を，その句のもつ意味合いに着目し，大分類を基に 段階的に分類している。なお，分類の際に，共通の記述がみられな いものについては, 分析対象要素として加味しないものとする。

次に，抽出された形容句とく面>の種類をクロス集計した結果， 延べ1602の組み合わせが得られ，これをもとにコレスポンデンス分 析を行い, 分類の相関を整理した（図 2 )。そして, コレスポンデン ス散布分布図をゾーニングすることで解釈した結果, 形容句と＜面 $>$ の種類の組み合わせは，構成により捉えられる<面>，性状により 
表 $2<$ 面 $>$ の種類

\begin{tabular}{|c|c|c|c|c|}
\hline & 分類 & 定義説明 & 記述例 & 抽出数 \\
\hline 面 & 【面】 & 物の外郭を成す角のないひろがり & 面 & 526 \\
\hline \multirow{4}{*}{$\begin{array}{l}\text { 云 } \\
\text { 恣 } \\
\text { 化 }\end{array}$} & 【平面】 & 物体を真上から垂直に見下ろした形 & 平面 & 125 \\
\hline & 【立面】 & 物体を真横から水平に見た形 & 立面/正面 & 56 \\
\hline & 【断面】 & 物体を切断したときの最外部, 切り口の形 & 断面/切断面 & 54 \\
\hline & 【側面】 & 物体の横側にあたる部分 & 側面 & 11 \\
\hline \multirow{5}{*}{$\begin{array}{l}\text { 構 } \\
\text { 成 } \\
\text { 部 } \\
\text { 材 }\end{array}$} & 【壁面】 & 壁の一番外側にあたる部分 & 壁面/外壁面 & 223 \\
\hline & 【屋根面】 & 屋根の一番外側にあたる部分 & 屋根面 & 16 \\
\hline & 【天井面】 & 天井の一番外側にあたる部分 & 天井面 & 16 \\
\hline & 【床面】 & 床の一番外側にあたる部分 & 床面/スラブ面 & 16 \\
\hline & 【空面】 & 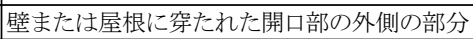 & 空面 & 10 \\
\hline \multirow{3}{*}{ 形 状 } & 【妻面】 & 建物の側面や棟の方向に直交する面 & 破風面 & 5 \\
\hline & 【曲面】 & 曲がっている厚みのない, 厚みの少ない物体 & 曲面 & 87 \\
\hline & 【斜面】 & 傾斜をもつたものの一番外側にあたる部分 & 斜面/傾斜面 & 52 \\
\hline \multirow{2}{*}{ 臭 } & 【水面】 & 液体の一番外側にあたる部分 & 湖面 /川面 & 28 \\
\hline & 【地面】 & 大地の一番外側にあたる部分 & 地面 & 9 \\
\hline \multirow{4}{*}{ 素 } & 【膜】 & 空間を隔てる薄い有機物 & 膜面/被膜 & 132 \\
\hline & 【皮】 & 物体を覆っている有機物 & 面皮 & 34 \\
\hline & 【布】 & 薄く広がりのある織物 & 幕 & 14 \\
\hline & 【皮膚】 & 生物の体表を覆っている有機物 & 肌 & 4 \\
\hline \multirow{2}{*}{ 像 } & 【境界面】 & 隣接するものを区切る面的な境目 & 境界面/結界 & 10 \\
\hline & 【スクリーン】 & 映像信号を表示するもの & スクリーン面 & 65 \\
\hline \multirow{2}{*}{ 層 } & 【表面】 & 物体の最も外側の部分, 外から目に付く部分 & 表面 & 50 \\
\hline & 【表層】 & 物体の外側において重なりをもつもの & 表層 & 8 \\
\hline \multirow{3}{*}{\begin{tabular}{|l} 
形 \\
式
\end{tabular}} & 【ファサード】 & 建物の外側を構成する主要な側面 & ファサード & 73 \\
\hline & 【顔】 & 物事の主要な一側面 & 顔 & 8 \\
\hline & \multicolumn{3}{|c|}{ 小計 } & 1644 \\
\hline
\end{tabular}

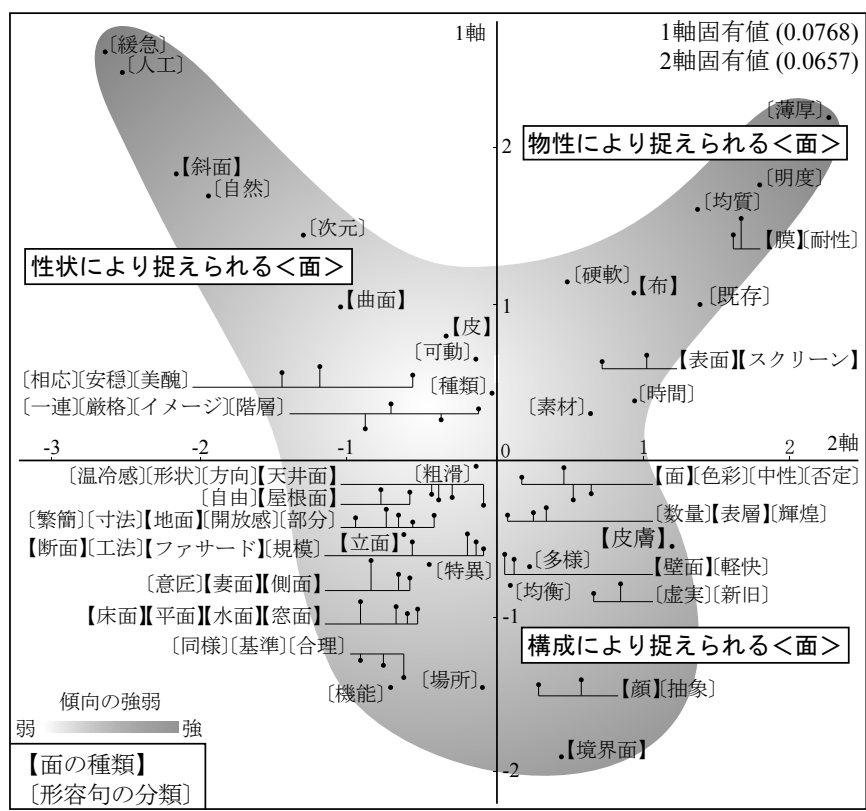

図 2 形容句と<面>の種類のコレスポンデンス分析散布図

捉えられる<面 >, 物性により捉えられる<面 $>$ の 3 つ整理できた。 以下にそれぞれの傾向を構成するのに大きく起因している周縁部の 要素の組合せについて述べる。

〔抽象〕は，【境界面】などと強い関連を示し，「曖昧な境界面」注3) などの描写により，境界面と他の事象との関係性を捉え，＜面>が 建築物の関係性を構成しているものとして表現している。また，〔場 所】は,【境界面】などと強い関連を示し,「日本的な仕切り結界」注4) などの描写から, 特定の地位性との関連性を捉え, <面>の構成に より特定の事象を連想するものとして表現している。これらは，構 成により捉えられる<面 >の性質が表現されているといえる。

〔緩急〕は,【斜面】や【曲面】などと強い関連を示し,「緩勾配の 斜面」注5) などの描写により, 形態変化の尺度を捉え, <面>の状態,
表 3 形容句の分類

\begin{tabular}{|c|c|c|c|}
\hline & 分類 & 記述例 & 工多 \\
\hline \multirow{5}{*}{ 获 } & 〔緩急] & 情を変化させる効果をもち, 緩やかな曲面が未来的 $\cdots$ & 19 \\
\hline & 〔薄厚〕 & 培から浮かび上がったガラスの薄い被膜面を際立たせ $\cdots$ & 16 \\
\hline & 〔形状] & サスペンション構造で, カテナリー状の曲面と中央に $\cdots$ & 194 \\
\hline & 〔粗滑〕 & 鉄筋コンクリートシェル構造の滑らかな曲面を内部の $\cdots$ & 43 \\
\hline & [イメージ] & でつくった扇子の様な特徵的な構造= & 19 \\
\hline \multirow{5}{*}{ 類 } & 〔多様] & 単純な輪郭のなかに仕掛けられたさ & 19 \\
\hline & 〔種類] & $\underline{3 \text { 種類の表面仕上げにすることで石に }}$ & 7 \\
\hline & 〔同様〕 & 庇はアルミの押し出し形材とし, 同一 & 3 \\
\hline & 〔相応 & 「ポルテ(門)」の名にふさわしいファサードを形成し… & 3 \\
\hline & [特異] & としてつくられているので，独自の斜面がそこに形成… & 18 \\
\hline \multirow{5}{*}{\begin{tabular}{|l} 
位 \\
置
\end{tabular}} & [場所] & 常々感じていることだが，旦本の天 & 18 \\
\hline & 〔次元] & 滑らかな三次元曲面は，造船鐃鉄法 & 22 \\
\hline & 〔方向] & 目線から見上げると垂直面のガラス & 197 \\
\hline & [基準] & 建物の基本断面は, 歴史に範を求め & 7 \\
\hline & [数量] & ズラしたり，傾けたりして，ひとつ & 88 \\
\hline \multirow{4}{*}{ 数 } & [寸法] & 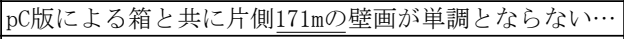 & 42 \\
\hline & 〔既存〕 & 同一面上に重ねたこと，連続する既 & 3 \\
\hline & 〔部分] & $7 \mathrm{~m}$ 後退させ, 全体の壁面が無理な & 43 \\
\hline & 〔時間] & オン照明は夜間のガラス面 & 4 \\
\hline \multirow{5}{*}{\begin{tabular}{|l|} 
価直 \\
\end{tabular}} & 〔合理〕 & 》は明解な平面計画と合理的 & 5 \\
\hline & [機能] & その結果, 面積効率のかなり良い機 & 9 \\
\hline & 〔意匠] & それぞれ軸を持った装飾的な壁面が & 26 \\
\hline & 〔虚実] & も仮想の平面を切り欠くことで，兆 & 5 \\
\hline & 〔美醜〕 & 弱いため, 四角い断面で直線のまま美し & 8 \\
\hline \multirow{4}{*}{\begin{tabular}{|l} 
状 \\
態
\end{tabular}} & 〔工法] & しる煉瓦平石積みのソリット & 19 \\
\hline & [人工] & 䰦い人工の皮膜の下に変わら & 3 \\
\hline & [抽象] & 丈透明にならない曖昧な境界 & 9 \\
\hline & [可動] & Eめに可動の幕が天井面に設 & 9 \\
\hline \multirow{7}{*}{ 実質 } & 〔新旧] & ース部品による新しい強化カ & 13 \\
\hline & [繁簡] & 主屋と使用人棟でT字型の単純な平而 & 16 \\
\hline & 〔規模] & スとしてできる限り大きな知 & 118 \\
\hline & [均質] & どこまでも均質な面に変化をつける & 6 \\
\hline & 〔軽快] & 複層させることにより軽快なファサー & 4 \\
\hline & 〔硬軟] & 長い年月を経たその硬い表面が, 部 & 29 \\
\hline & 〔素材] & 产面は既存の設備類や老化し & 327 \\
\hline \multirow{4}{*}{\begin{tabular}{|l} 
刺 \\
激
\end{tabular}} & 〔明度〕 & 水平を強調させたその上の中間部は，陰影のある壁面… & 60 \\
\hline & [輝煌] & バーチ合板の, その明るい色, 固く光沢のある & 10 \\
\hline & 〔色彩] & 上うなモノリシックな白い壁 & 43 \\
\hline & 〔温冷感〕 & 触っても冷たさを感じないケミカルブラスト表 & 3 \\
\hline \multirow{5}{*}{\begin{tabular}{|} 
変動 \\
严
\end{tabular}} & 〔而性〕 & 耐候性をもつた建築の表面を透明にし，あるいは鏡面… & 6 \\
\hline & [一連 $]$ & 分棟した建物を結び付ける要素は, 一連の曲面が描く $\cdots$ & 19 \\
\hline & [均衡] & の緊張には，軸線をずらした新たな対称の平面が干渉… & 13 \\
\hline & [階層] & この建物も参道に面して何重ものファサードを重ねる… & 18 \\
\hline & 〔開放感] & 外に開かれている断面と, 内にふく & 13 \\
\hline \multirow{2}{*}{\begin{tabular}{|l} 
臭 \\
\end{tabular}} & [中性] & 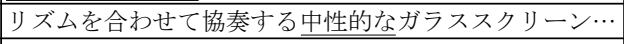 & 3 \\
\hline & 〔自然] & 緑の草面は均一の整った色彩に萌えてゆったりと大き… & 17 \\
\hline \multirow{4}{*}{\begin{tabular}{|l} 
性 \\
向
\end{tabular}} & 〔否定〕 & 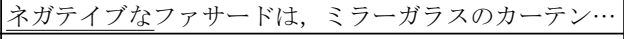 & 4 \\
\hline & 〔自由〕 & 自立壁のように扱うことによって，自由な断面が計画… & 11 \\
\hline & 〔稂格] & シンメトリカルでやや権威的なファサードを意図した. & 7 \\
\hline & [安穏] & ヨーロッパ広場側へと大らかな曲面を描くガラスファ… & 6 \\
\hline & & & 1602 \\
\hline
\end{tabular}

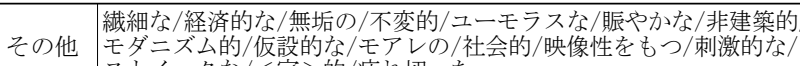
モダニズム的/仮設的な/モアレの/社会
ストイックな/<家＞的/疲れ切った

※その他の記述例は，共通の記述が少なく，どの分類にも属さないもの ※下線部は形容句の抽出箇所

※記述例の引用元『新建築』( 上から ) p.216,1993.2/p.124,2000.3/p.100,1998.1 /p.175,2009.3/p.184,2005.9/p.196,1988.3/p.100,2007.4/p.208,2007.12/p.250,1994.5/p. $210,1979.7 /$ p.180,2005.8/p.187,2005.11/p.113,2001.9/p.119,2002.9/p.136,2008.8/p.77, $2003.12 /$ p.215,1984.6/p.274,1984.10/p.172,2004.9/p.312,1990.2/p.256,1971.5/p.240,19 80.8/p.163,2007.11/p.89,2004.3/p.172,1966.8/p.78,2007.1/p.290,1992.8/p.231,1951.8/p $.178,2003.5 /$ p.53,2003.9/p.288,1988.6/p.168,1983.8/p.208,1999.4/p.177,2000.7/p.176,1 997.6/p.154,2009.3/p.251,1996.3/p.177,2009.11/p.319,1989.8/p.194,1983.4/p.191,1967 $.2 /$ p.178,1981.8/p.98,2004.8/p.232,1980.4/p.200,1996.9/p.171,1993.9/p.228,1989.10/p. 250,1979.6/p.264,1989.6/p.109,2006.6

性状をより具体的に表現している。また，〔次元〕は，【曲面】など と強い関連を示し，「3 次元的な曲面」注6) などの描写により，＜面> の広がりや存在を捉え，＜面>を空間と同時に語ることで，座標的 
な視点から表現している。これらは, 性状により捉えられるく面 $>$

の性質が表現されているといえる。

〔薄厚〕は,【膜】などと強い関連を示し,「薄い皮膜」注7)などの 描写により，物質としての厚さを捉えることで，部材としてく面 $>$ がもつスケールを印象的に表現している。また，〔明度〕は，【膜】 や【表面】などと強い関連を示し,「透明な膜柱」注8) などの描写に
より, 光の透過性を捉えることで, 何かを覆うく面 $>$ の視覚的特徴 を表現している。これらは，物性により捉えられるく面>の性質が 表現されているといえる。

\section{6. 作用句と<面>の種類のコレスポンデンス分析}

抽出したく面 >の作用句を分類する（表 4 ）。本稿では，抽出した

表 4 作用句の分類

\begin{tabular}{|c|c|c|c|c|c|c|c|}
\hline & & & & & & & \\
\hline & 分類 & 記述例 & 抽出数 & & 分類 & 記述例 & 抽出数 \\
\hline \multirow{7}{*}{ 䡬移 } & \multirow{2}{*}{ [遮断] } & $\begin{array}{l:l}\mathrm{C} & \ldots \text {. 西面をできるだけ䦚鎖する形をとった. } \\
\end{array}$ & \multirow{2}{*}{41} & & \multirow{2}{*}{ [変形] } & 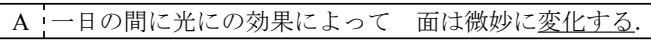 & \multirow[b]{2}{*}{91} \\
\hline & & D：隣地からの視線だけを遮断する柔らかなスクリーン $\cdots$ & & & & 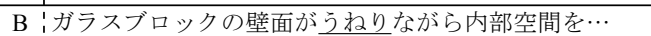 & \\
\hline & [変位 $]$ & $\begin{array}{l:l}\mathrm{C} & \text { 東側正面の壁面と南西角の壁面を後退させ } \cdots \\
\end{array}$ & 24 & \multirow{3}{*}{ 蓉 } & \multirow{2}{*}{ [展開] } & 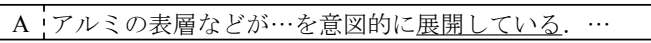 & \multirow[t]{2}{*}{4} \\
\hline & \multirow{2}{*}{ [向合] } & A & \multirow{2}{*}{15} & & & 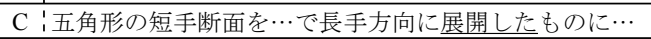 & \\
\hline & & 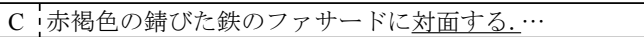 & & & [透過] & $\begin{array}{l}\mathrm{C} \text { ：半透明の面を透過した光や，鈍い反射光は柔らかい } \ldots . \\
\end{array}$ & 19 \\
\hline & \multirow{2}{*}{ [浮遊 $]$} & 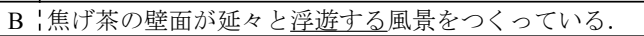 & \multirow{2}{*}{8} & \multirow{2}{*}{\multicolumn{2}{|c|}{ [適応] }} & $\mathrm{A} \mathrm{A}$ ：外観と厚く深い軒とは周囲の山稜に照応させながら, $\cdots$ & \multirow{2}{*}{4} \\
\hline & & 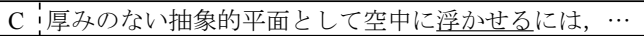 & & & & 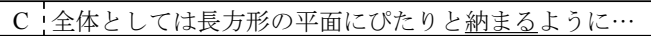 & \\
\hline \multirow{10}{*}{ 離 } & \multirow{2}{*}{ [接着］ } & A & \multirow{2}{*}{30} & & \multirow{2}{*}{ [対立] } & A & \\
\hline & & C 層状ファサードを中高層棟の両側に取り付けることで, & & & & C：旧い壁面と刺激的に対立するオブジェとなり，‥ & 10 \\
\hline & [扩散] & A ：テント幕は，音を反所・拡散し. & 5 & & & A：グレイのコンクリート面がよく似合うだろうと. & \\
\hline & [払双 & 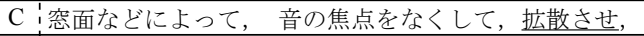 & 5 & & [D次 & 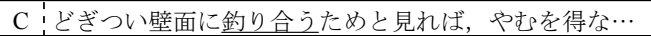 & 42 \\
\hline & 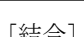 & 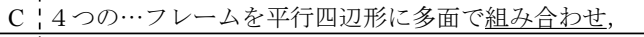 & 71 & & [利 & ４：フレキシビリティのある平面が採用された. & \\
\hline & 【楁口」 & D 【パネルを炭め込まれた南立面は， $\cdots$ & 11 & & [相] & $\begin{array}{l}\mathrm{C} \text { ：西側の斜面を利用してロックガーデンとし，東側の } \cdots \\
\end{array}$ & 18 \\
\hline & [淖結] & B：ジグザグ型の平面は南北の景観を連続させる効果が & 26 & & [確保] & A：安定した被膜が得られず, & 23 \\
\hline & 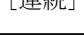 & 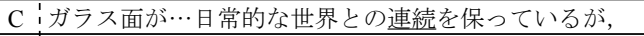 & 20 & & [㫿休」 & 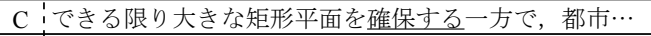 & 23 \\
\hline & [接触] & $\begin{array}{c:c}\mathrm{A} & 3 \text { 面が外気に面する計画とし, } \cdots \\
\end{array}$ & 28 & & & \begin{tabular}{c:c|l}
$\mathrm{A}$ & 外に開かれている断面が交互に並列している \\
\end{tabular} & \\
\hline & & $\mathrm{C}$ ：光庭は2面をオフィスに，2面をコアに接し， $\cdots$ & & & 【設撤」 & C：：東西に大きなガラス面を設けることとなった今回の $\cdots$ & 58 \\
\hline & & A：ネガティブなファサードは，‥によって実現される. & & & [所有] & 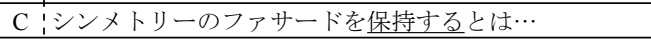 & 21 \\
\hline & [夫現] & 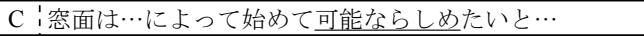 & 20 & 動 & & 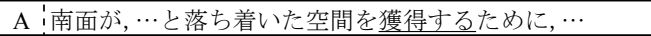 & \\
\hline & 「地出] & $\begin{array}{l}\mathrm{A} \\
\end{array}$ & $6-1$ & & 【獀得」 & 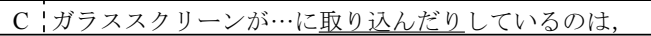 & 17 \\
\hline & 〈抽山 & 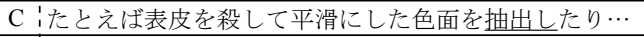 & 0 & & & 面は全てノセコートで防水した. & \\
\hline & 「出沉 & $\begin{array}{l}\mathrm{B} \text { ：新らしい立面，景観が出現するであろうことを期待 } \cdots \\
\end{array}$ & 52 & & [加上] & ートの表面を仕上げるとデザインが... & 55 \\
\hline 出 & 【出伇」 & $\begin{array}{l}\mathrm{C}\end{array}$ その肌を露出することに見なれているが. & & & & 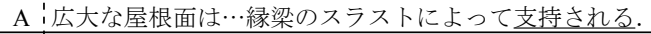 & \\
\hline & [埋没 & C：電燈で床上 $30 \mathrm{~cm} の$ 壁面に埋込み取付けてある… & 7 & & 【文持」 & 面も透明ガラスリブによって支えられている. & 9 \\
\hline & [包团] & 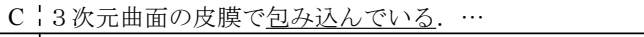 & 141 & & & C：スリットなど, 人目につかない面に塗られた色が, ‥ & \\
\hline & [LE由 & D ，覆うテフロン幕をどのようにして $\cdots$ & 141 & & 【偖仰」 & $\mathrm{D}$ ）着彩された大きな色面となって, $\cdots$ & 8 \\
\hline & [被覆] & 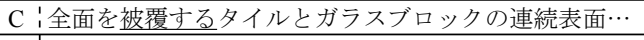 & 45 & & & $\mathrm{~A}$ ：軒枠で見切って南北面を強調し， $\cdots$ & \\
\hline & 〔权復 & D：被覆されたガラス面がリズミカルな表情をつくり & 45 & & 【强訶」 & 塗りわけられ対立性をきわだたせている, & 28 \\
\hline & [映写] & B：太陽の動きなどをその表面に刻々と映し出している.… & 36 & & [青現] & 目は端正さを表現する & \\
\hline 自 & & 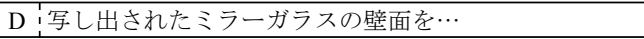 & & & [衣况] & 端面をわかりやすく表現することに腐心した. & 55 \\
\hline & $\Gamma=$ & A：間接照明の光により, 曲面天井全体が淡く面発光し, & 20 & & [復元 $]$ & C：「明治生命館」の東面の立面を修復することとなった. & 6 \\
\hline & [光] & 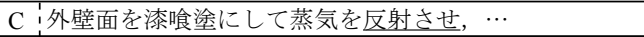 & 30 & & 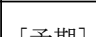 & ·れており,場内の劇的思索 & \\
\hline & 「鑘成] & A：自然と南面が増大してしまう. & 4 & & 了期」 & 被膜を想定して & 8 \\
\hline & 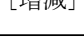 & B ：壁面を減らし金砂子をまいた襖の面を堌すなどして, & 4 & & & のくさりを考慮して，… & 31 \\
\hline & [形成] & A：立てハゼ亘きが, ベコベコした感じの反射面を形成し， & 76 & & 几配思。 & 面が無理なく視界に入るように & 31 \\
\hline & גדגורות & 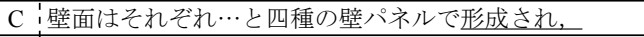 & 10 & & & 基準とする立面とがきまり, & \\
\hline & [分㓻] & C ：カーテン・ウォールの壁面を分割する方法には. & 31 & & 【設正] & C：湾曲する壁面を設定し，その片側に土を & 16 \\
\hline & [ย地 & D：グリッドに分割された被膜がその背後に. & & & & A :スロープ面, ․が，集約され全体像へと依存している. & \\
\hline & [生成] & A :ガラスで壁面がつくられている. & 56 & & 关了 & 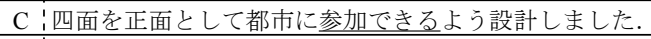 & 12 \\
\hline 増 & & C :三角形の各面が垂直面に対して…傾斜を生じることが, & & & & C：南面を積極的に開放し， ․ & \\
\hline 隇 & [統一] & 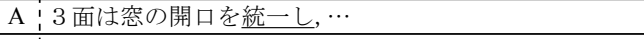 & 11 & & & $\mathrm{D}$ D：開放された水平床面と開口は $\cdots$ & 31 \\
\hline & & C：内壁はラワンベニヤの壁面で統一し,仕上は材質を生 & & & [諉道] & 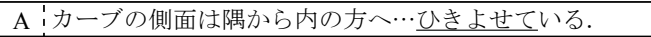 & \\
\hline & [聐失失 & $\mathrm{A}$ ：鉄筋コンクリートの表面からは，‥を消し去った. & & & 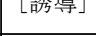 & 供たちの想像や遊びを誘発 L & 46 \\
\hline & [1]人] & C：柱はステンレスの鏡面で覆って存在感を消した. ‥ & 1 & & & A：同様に「シームレス」な表層が求めら & \\
\hline & [創出] & 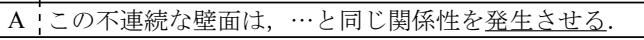 & 26 & & [必要] & 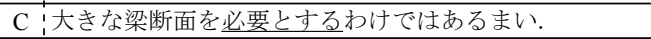 & 11 \\
\hline & 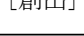 & C：異なった表面を提供している. & 20 & & & ａ：背景となる部分は屏風状の凹凸の曲面で構成し… & \\
\hline & 「右纴] & 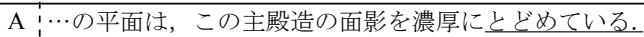 & & 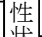 & [構) & 面と仕上げ材で構成され， & 57 \\
\hline & [保机 & C：ガラス面をできるだけ高温に保つことによって & 19 & & 周 & A！既存の道路と斜めに接する西壁面が建物を特徵付け·. & 7 \\
\hline 変 & 「唖市 & A 4 4つの面が衝立するように立ち上がり $\ldots$ & 20 & & ไ曰 & C :ガラス面でその境界を定義付けられるが， & \\
\hline 容 & {$[\mathrm{HC} C \mathrm{II}]$} & D：アトリウムの両側に屹立する “木”の大壁面は… & & & [有用] & A：湾曲するアルミの壁面は，構造的にも直利に働き， $\cdots$ & 8 \\
\hline & & & & & & 小計 & 1609 \\
\hline
\end{tabular}
※その他の記述例は, 共通の記述が少なく, どの分類にも属さないもの

※アルファベットAからDは作用句の種類，下線部は作用句の抽出箇所

※アルファベットAからDは作用句の種類,

p176.1963.6/p.149,1999.10/p.219,2000.3/p.234,1976.4/p.316,187,1986.4/p.335,1990.5/p31,1989.9/p.200,1996.6/p.136,2008.5/p.258,1989.3/p.193,1981.10/p.250,1974.9/p.167,1975.3/p.163,1981.3/p.10,1958.12/ p.211,1992.5/p.228,1989.10/p187,1998.8/p.143,1968.3/p.37,1958.7/p.196,1966.11/p.10,1954.2/p.324,1992.3/p.112,1999.1/p.198,1985.10/p.226,1983.4/p.248,1982.3/p.168,1983.8/p.210,1980.4/p.213,1980.2/p.1 87,1998.8/p.228,1992.6/1999.2.173/p.170,1995.10/p.230,1981.7/p.132,1950.5/p.75,1981.7/p.290,1981.2/p.10,1953.3/p.68,1955.10/p.171,1952.4/p.156,1984.10/p.224,1986.1/p.50,1955.11/1952.5/p.176,2004.9/p $.259,1987.12 /$ p.61,1956.11/p.70.1958.6/p.23,1959.7/p.245,1997.1/p.228,1952.5/p.286,1990.2/p.189,1981.1/p.131,2004.11/p.37,1956.2/p.60,2002.7/p.203,1971.6/p.47,1961.6/p.191,1967.2/p.12,1958.7/p.178,200 3.5/p.170,1981.7/p.204,2007.10/p.24,1955.11/p.192,1991.2/p.192,1970.5/p.106,2001.9/p.165,1963.6/p.104,2005.1/p.429,1952.9/p.245,1975.1/p.38,1953.12/p.135,2009.5/p.215,1983.8/p.206,1997.1/p.91,2002.4/ p.385,1951.12/p.75,2004.10/p.39,1959.12/p.182,1966.11/p.274,1984.10/p.23,1960.7/p.241,1981.2/p.207,1965.4/p.162,1951.5/p.176,1969.9/p.91,2007.4/p.256,1981.9/p.83,1955.5/p.67,1956.4/p.191,1997.3/p.48, 
作用句を，その句のもつ意味合いに着目し，大分類をもとに分類し ている。この分類内において，＜面>の種類と主述の関係のある文 節を $\mathrm{A}$, 複文における副次的な主述の関係を構成している文節を $\mathrm{B}$, <面 $>$ の種類から修飾を受ける文節を $\mathrm{C}$, 文章描写の中で $<$ 面 $>$ の 種類に対して作用的性質の強い文節をDとして分類している。なお, 分類の際に, 共通の記述がみられないものについては分析対象要素 として加味しないものとする。

次に, 抽出された作用句とく面>の種類をクロス集計した結果, 延 ベ1609の組み合わせが得られ，コレスポンデンス分析を行い，分類 の相関を整理した（図 3 )。そして，コレスポンデンス散布分布図を ゾーニングすることで解釈した結果，作用句と $<$ 面 $>$ の種類の組み 合わせは, 事象を位置づけるく面 $>$, 高い存在価值をもつ<面 $>$, 空間を構成するく面 $>$, 高い計画性をもつ<面 $>$ の 4 つ整理できた。 以下にそれぞれの傾向を構成するのに大きく起因している周縁部の 要素の組合せについて述べる。

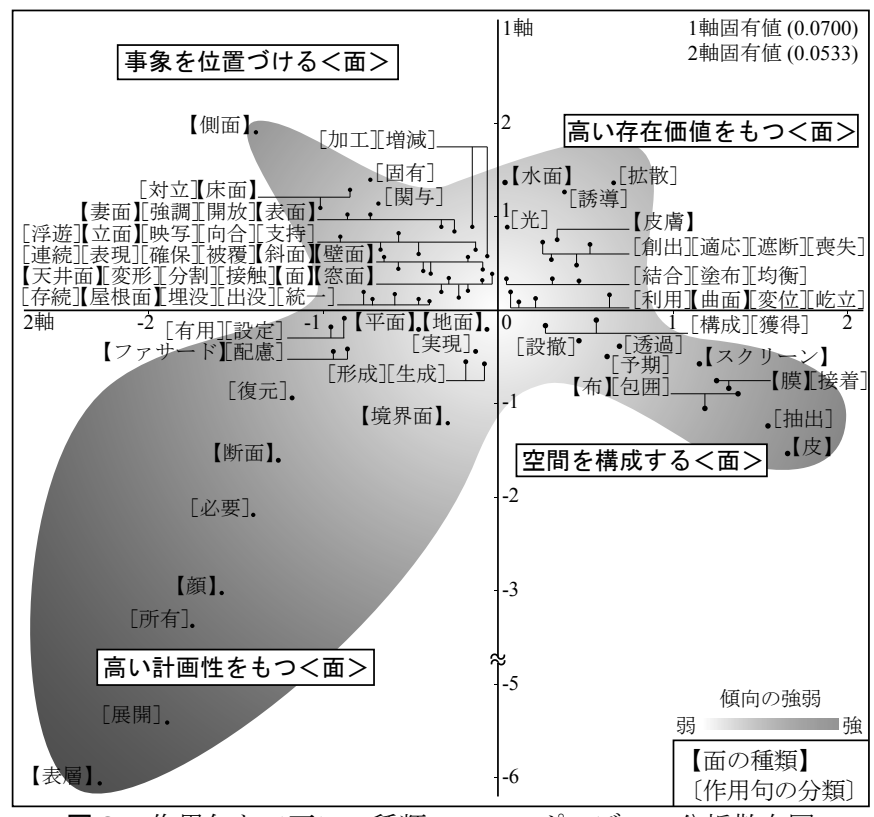

図 3 作用句と<面 $>$ の種類のコレスポンデンス分析散布図

[ 関与 ] は，【側面】などと強い関連を示し，「傾斜した側面は，斜 線制限に起因し」注9) などの描写により，〈面>の主体性や客体性を 捉え，＜面>が他の事象に影響を受けたり与えたり寸るものとして 表現されている。[開放］は,【床面】などと強い関連を示し，「開放 された水平床面注」注10) などの描写により，建築物を構成する＜面> の公開性を捉え，構成要素である<面 >の建物内や地域における位 置づけを表現している。これらは，＜面＞が事象を位置づけるもの として表現されているといえる。

[誘導］は，【水面】などと強い関連を示し，「セントローレンスの 河面が，夕景にはモントリオールのビルにきらめく無数の灯りを映 して, 一瞬鮮やかに現実の世界を呼びもどす」注11)などの描写により， 空間を構成する＜面 $>$ と人の感情や行為との係わりを捉え，＜面 $>$ が人の行為を促すものとして表現されている。［遮断］は，【皮膚】 などと強い関連を示し，「古皮質，旧皮質に隠蔽した」注12) などの描 写により, 空間に存在するく面 $>$ 表側と裏側を捉え, 境界となる <面>が必要としないものを断ち切るものとして表現されている。
これらは，＜面>自体の存在が高い価值をもつものとして表現され ているといえる。

[接着]は，【皮】などと強い関連を示し，「化けの皮がはが れ」注13)などの描写により，物体を覆うく面〉と物体との接続部分を 捉え，＜面>が物体の表面に付属されるものとして表現されている。 [包囲］は，【布】などと強い関連を示し，「アルミパンチングメタル の半透明の膜が張り巡らされ」注 14) などの描写により，＜面>の空間 を構成する役割を捉え，〈面＞が外部環境から人を保護するものと して表現されている。これらは, 空間を構成するものとして表現さ れている。

[所有］は,【表層】などと強い関連を示し，「特異な表層を持 つ」注15) などの描写により，建築物を構成するく面>のもつ性状を捉 え，＜面>が特徴的な意匠や性能をもたらすものとして表現されて いる。また, [必要] は, 【顔】などと強い関連を示し,「新たな顔が 求められた」注16) などの描写により，＜面>自体を要求される要素と して捉え, 要求に応えるく面 >が新たな付加価值をもたらすものと して表現されている。これらは，＜面＞が高い計画性をもつものと して表現されているといえる。

\section{7. 形容句と作用句からみるく面 $>$ の多義性}

前章までの形容句と＜面>の種類のコレスポンデンス分析散布図 のゾーニングによって得られた 3 つの意味の傾向と作用句と<面 $>$ の種類のコレスポンデンス分析散布図のゾーニングによって得られ た 4 つの意味の傾向から, 前者を縦軸, 後者を横軸にもつマトリク スを作成し，全資料をプロットした（図 4)。これにより，各研究対 象の記述に含まれる形容句，作用句がどのような意味の傾向に属す るかを整理するとともに，その組み合わせから，原文の記述内容を 考慮し，合議制の親和図法により比較検討をすることで判別を行っ た。なお, 研究対象のなかで, 形容句と作用句の要素が共にコレス ポンデンス分析散布図の原点付近に布置される組み合わせが延べ 311 みられたが，これらは類型を判断する上で影響がない要素であるこ とから, 図への表記は省略した。

以上により, 建築物の言語描写におけるく面 $>$ の多義性として, 少なくとも $\mathrm{A} \sim \mathrm{S}$ までの 19 のく面＞を語義の類型として導き出すこ とができた注17)。以下に，導出した多義について考察する。

A は建築物における構成単位としての＜面＞である。このような ＜面＞は，「大きなガラスの壁面はどこまでも広がる。」注18) などのよ うに，【壁面】が〔規模】，〔方向〕などと組み合わさることで，建築 物の水平方向における構成が表現されている。その上で, [加工], [支 持］, [変形] などと組み合わさり, 建築物の垂直方向や曲面での構 成が表現されている。これにより，水平方向におけるく面 $>$ を建築 物の構成単位として捉え, 垂直方向や曲面に構築していき, 部分の 集合により建築物を構成している。

B は対比における存在の強調としての<面>である。このような く面＞は,「美しく小さな水面によって浮き立たせ」注19)などのように、 <面>が事象との対比的な関係により捉えられる描写である。材料 や自然などの【表面】や【水面】が質感, 硬度などの違いによる相 対的な関係が表現されている。形容句の〔規模〕，〔方向〕が作用句 の [強調 $],$ [関与 $]$ と組み合わさることで, 建築物の規模や方向性 をより強調させている。 
C は歴史的付加価值の保持としての<面>である。このような ＜面＞は，「既存の北側外観は全面外壁保存」注20)などのように，建 築物を構成するものとして描写され，【ファサード】などが，〔規模〕， ［存続］などと組み合わさることで，＜面 >の時間軸やその土地がも つ歴史などが表現されており, 建築物を構成するく面 $>$ の経年変化 が，維持，制御されている。

Dは現象を映す表現媒体としての＜面＞である。このような＜面＞ は，「浜名湖の湖面にその姿をうつしている」注21) などのように，自 然光など不定形な事象と係わるものとして描写され，【水面】などが， [映写]，〔場所〕などと組み合わさることで，光の反射性が表現され ており，現象を映す表現媒体としての<面 >を表現している。

E は事象性を帯びる表現媒体としての＜面＞である。このような ＜面>は，「ジグザグのガラス面で写り込み」注22) などのように，建 築物としての<面 $>$ が，自然や風景などと係わるものとして描写さ れている。外部環境に接する【面】などが，〔素材〕，[映写〕と組み 合わさることで, 自然や風景との視覚的な一体化, もしくは調和す る表現媒体としての<面 $>$ が表現されている。

F は関係性を構築する境界としての<面 $>$ である。このような ＜面＞は，「傾斜した空面などによって，音の焦点をなくして」注23) などのように，＜面＞が事象間を関係づけるものとして描写されて いる。【空面】などが〔方向〕，[喪失］と組み合わさることで，大き さや方向性をもつものとしてく面 >が捉えられ，関係性を構築する 境界としての $<$ 面 $>$ を表現している。

Gは性能を付加する表層としての＜面＞である。このような＜面＞ は,「“チタン”といわれる金属をタイルの表面に 2 度焼きをして蒸 着させたもので」注 24$)$ などのように, 建築物の構成単位として, <面> 自体が描写されている。材料における【表面】などが, [素材], [加工] などと組み合わさることで，建築物を構成している素材が建築物に 表層として納まるものとして表現されている。

Hは行為を制御する構成部材としての＜面＞である。このような ＜面＞は，「タイルを貼った壁面が子供たちの想像や遊びを誘発して くれればと考えた。」注25)などのように，＜面＞が事象と係わりを制 御する働きのあるものとして描写されている。作用句が，＜面 > 自 体のもつ性質や状態などの特徴を意味付ける側面が強く，【壁面】な どが，〔素材〕，[誘導]などと組み合わさることで，＜面＞自体が人 に対して想像力や行動を喚起するものとして表現されている。

I は秩序を創出する表層としての＜面＞である。このような＜面 $>$ は,「ガラス面が元より VERTU のブランドカラーに合っていた」注26) などのように，建築物の構成に関わるものとして描写されている。 【面】などが，〔素材〕，[均衡〕などと組み合わさることで，建築物 を構成する部分としての<面 $>$ が，秩序を創出する表層として表現 されている。

$\mathrm{J}$ は外部環境を調整する構造体としての＜面＞である。このよう な＜面＞は，「南・西面は外付けブラインドで遮光し」注27) などのよ うに，<面＞が調整機能として描写され，特に外部環境と係わるも のとして描写されている。外部環境に対する【スクリーン】などが, 〔方向， [遮断]などと組み合わさることで，方向性や大きさを伴っ て外部環境と物理的に遮断するものとして表現されている。

Kは領域を限定する実体としての＜面＞である。このような＜面 $>$ は, 「庭に面する南面と西面の外壁面はすべて透明のガラスでエンク
ローズしており」注28) などのように, 作用句による影響が強くみられ， 【壁面】などが，〔方向】，[包囲ななどと組み合わさることで，外部 環境から生活を保護する境界として捉えられ，＜面＞が空間を覆う， あるいは，取り囲む構造体として表現されている。また，【壁面】が， [可動], [設徹]と組み合わさることで, <面 >が内部空間における, プライバシーの保護, 獲得や機能の分節を可能にする構成要素とし て表現されている。

L は効果的な構造体としての<面 >である。このような＜面＞は， 「層状の平面はその利用に大きな強制力を発揮することとなり」注29) などのように，＜面＞が構造体の性能を評価するものとして表現さ れ，また，建築の構造的な安定性を確保する役割をもったものとし て表現されている。【平面】などが，〔階層〕，[有用］などと組み合 わさることで，建築物のなかで効果的な働きをする構造体としての ＜面＞として表現されている。

Mは透過性をもつ実体としての＜面＞である。このような＜面 $>$ は，「セラミックプリントの薄膜を通して」注30) などのように，＜面> 自体が実体をもつものとして描写され，〔素材〕，〔薄厚〕などの形容 句によって，それが限りなく厚みの少ない物体として捉えられた上 で, [透過］といった作用句と組み合わさることで, 建築空間において, ＜面＞が様々な事象を透過するものとして表現されている。

$\mathrm{N}$ は認識により出現寸る境目としての＜面＞である。このような ＜面>は，「鉄筋コンクリートの表面からは，その素材をあらわにし た部分と打増しやペイントによるグラフィカルな衣をまとった部分 との際立つ対比によって，打放しコンクリートの持つ必要以上の重 量感を消し去った。」注31) などのように，事象や事物同士の関係を捉 えることで出現する認識の上での境目として描写されている。実空 間の構成により捉えられる【表面】などが，〔素材〕，[喪失〕と組 み合わさることで，＜面＞が認識により出現する境目として表現さ れている。

O は生産性を向上寸る構成部材としての＜面＞である。このよう なく面>は，「梁には 2 段構えの方杖方式を採用することで経済的な 部材断面を求め」注32) などのように，＜面＞自体の性能や役割が描写 されている。【断面】などが，〔経済〕，〔必要〕などと組み合わさる ことで，＜面>の建築計画における経済的側面，施工期間における 作業効率の向上が捉えられ，施工計画上の諸条件に対する $<$ 面 $>$ の 生産性が表現されている。

$\mathrm{P}$ は空間性能に寄与する形状としての<面>である。このような く面>は，「ストライプ状に乳白色のフィルムを貼られた大ガラス面 がスクリーンとして設定される。」注33) などのように，【面】などが， [規模]，[設定］などと組み合わさることで，＜面>の形状が建築空 間に及ぼす効果が捉えられており，〈面〉が機能的な側面をもつも のとして表現されている。また，[規模〕，[配慮］などが組み合わさ ることで，＜面>の形状が，建築空間の性能に大きく作用するもの として捉えられており，計画における慎重を期す検討事項として表 現されている。

Q は計画過程における二次元化としての<面 >である。このよ うな $<$ 面 $>$ は, 「南側は田園風景と対峙する $400 \mathrm{~m}$ の壁面を屈折さ せ,」注34) などのように，〈面>の環境に対する変容を描写している。 形容句と作用句が組み合わさることで意味付けられる側面が強く, 【壁面】などが，〔寸法]，[変形]などと組み合わさることで，周辺 


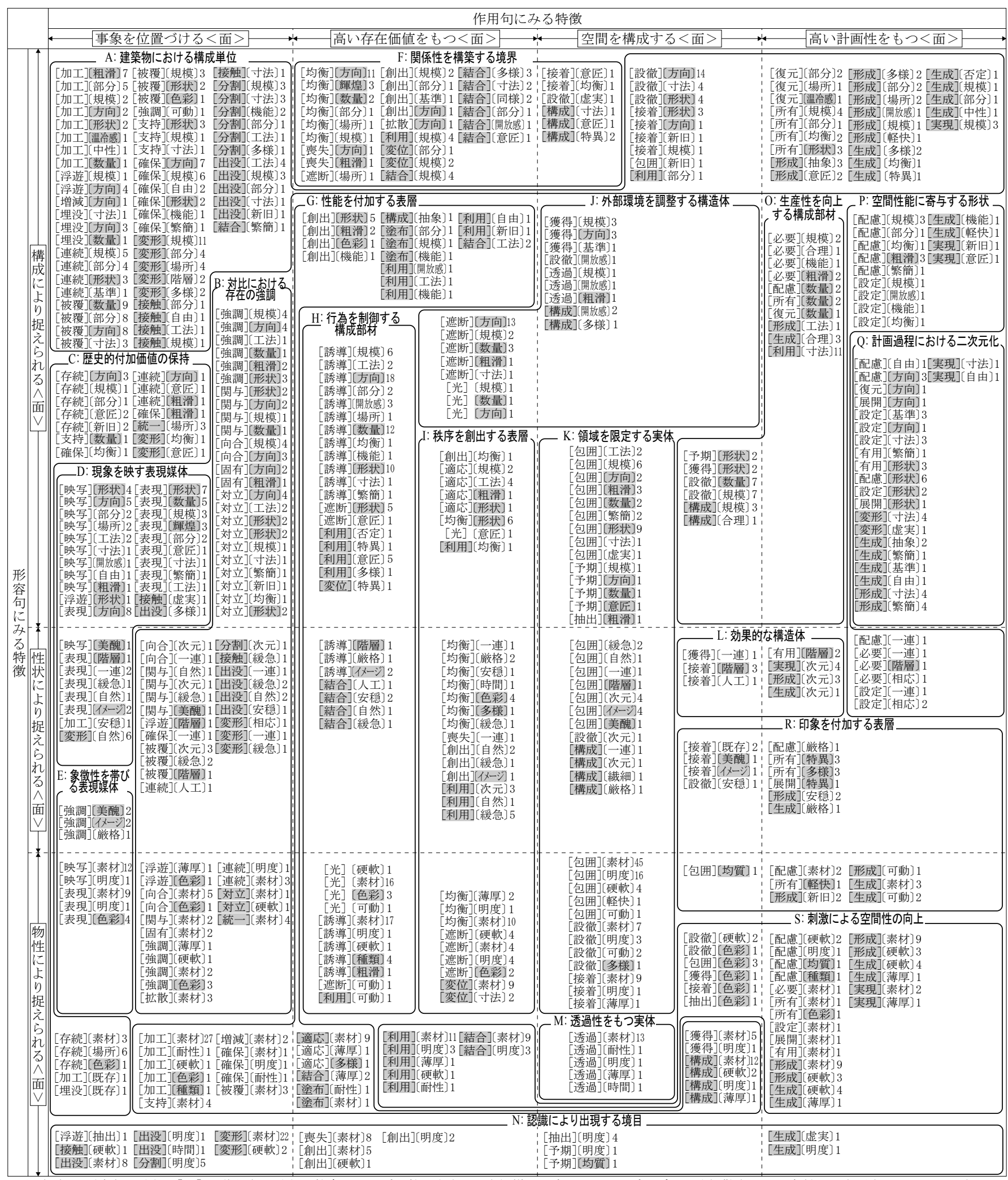

※注〔］は形容句の分類, [ ] は作用句の分類, 数字はサンプル数を表す。図中網掛け要素は, コレスポンデンス分析散布図の原点付近に布置されたものを示す。

図 4 形容句と作用句からみる<面 $>$ の多義性

環境に対しての面の存在や見え方を表現している。また, [方向]，[配 慮」などと組み合わさることで，＜面＞を特徴づけるものとして表 現している。

Rは印象を付加する表層としての<面 >である。このような＜面 $>$ は,「やや権威的なファサードを意図した。」注35) などのように, <面>
の存在強度を付加する描写である。形容句により意味付けられる側 面が強く,【ファサード】などが〔箃格], [配慮〕と組み合わさるこ とで, <面>の存在感や厳格さが, 人に緊張感や圧迫感などの印象 を付加するものとして表現されている。また，〔素材，［配慮］など と組み合わさることで, ガラスなどの素材の透明感や透過光の柔ら 
かい光が，＜面>の印象を付加する表現をしている。

$\mathrm{S}$ は刺激による空間性の向上としての<面 >である。このような ＜面＞は，「隣地からの視線だけを遮断する柔らかなスクリーンを考 え」注36) などのように，<面>と事象との係わりにより捉えられる描 写である。【スクリーン】が，〔硬軟〕，[配慮]などと組み合わさり， 質感や感触, 硬度などの違いによる刺激を与える＜面＞として表現 されている。

\section{8. 結論}

本研究では, 建築家の言語描写における面の多義性について, 形 容句，作用句及び描写内容から考察を行った。その結果，建築物に おける言語描写として 19 種の多義性を導き出すことができた。

建築物の言語描写における面は, 形容句という側面からみると, 面自体の建築物の構成単位としてのふるまいや硬さ，粗さなどの面 の質感に関する描写により, 物質性が強調され, 具象化されること で実体として存在していた。その一方で，人が触れる，見るなどの 触覚や視覚に対する面の触感において，柔らかな，滑らかななどの 面の肌理に関する描写により，面の連続性が強調され，概念化され ていくと同時に，面が空間認識や記憶，感情という人の内面に働き かけていた。作用句という側面からみると，事象との組み合わせに 関する描写により，面は物理的な計画性や，空間あるいは場を形成 するものとして存在していた。さらに, その事象との関係性において, 対比的あるいは相対的な描写がされることによって, 面がその他の 事象を表現する主体となっていた。その一方で，面自体の変化に関 する描写において，周囲の状況が面に変化をもたらし，あるいは面 が周囲の状況に変化をもたらすことで，空間との間に高い相関関係 をもった存在として表れていた。

以上のように，建築計画において，建築家独自の思想により解釈 され，意味づけられ，言説として描写された面の多義性を明らかに することができた。

\section{謝辞}

本稿を進めるにあたって, 大井亮氏（株式会社スペース），山梨岳 美氏 (名古屋工業大学大学院工学研究科博士前期課程), 森川祐喜氏 (株式会社大林組), 坂口大史氏 (名古屋工業大学大学院工学研究科 博士前期課程）には資料，論文作成にあたり多大な御協力をいただ きました。文末ではありますが，ここに記して感謝申し上げます。

\section{注}

注 1) 本稿における<面 >の定義は, 広辞苑, 大辞林, 建築大辞典, 日本語 新辞典, 辞林 21 , 国語大辞典 言泉, 新潮現代国語辞典, 新明解国語 辞典の「面（めん）」を参照し定義している。（参考文献 8～1 5 ）

注 2) 本稿では, <面>の種類, 形容句, 作用句を研究対象から抽出してお り, これらの語の描写内容が表す意味と照らし合わせて結論を導出し ている。そのため，考察や図中に扔ける「」内の記述例では，抽出元 となった研究対象を考察内容や図の表現内容に合わせて, 品詞の活用 の変換や文章の省略を行い例示しているが，文法上の表現を変えても これによる本稿の結論に対しての影響はないものと考える。

注 3) 堀場弘：ベイ・ステージ下田, 新建築, p.114, 2001.1

注 4) 山下設計+リカルド・ボフィル：ラゾーラ川崎プラザ，新建築，p.125, 2006.12

注 5） 菊竹清訓；斜面の意味；新建築，p. 214, 1979.7

注 6）東京理科大学情報メディアセンター，新建築，p. 205，1998.9

注 7）高砂正弘；森のトイレ 茨城氏青少年野外活動センター; 新建築, p. $166,2000.8$

注 8）千葉市建設局建築部営繥課 A\&T 建築研究所; 千葉市花の美術館新建築, p. $214,1996.2$

注 9) 千代田建築研究所; 熊野市民会館; 新建築, p.201, 1972.3

注 10) 村上徹建築研究所; 鈴ヶ台の家, p.241，1981.2

注 11）武基雄 ; 日本万国博 EXP070 への提言 ; 新建築, p. 201，1972.3

注 12） 竹山実建築総合研究所 ; ホテル・リバー・トム, p. 216, 1974.1

注 13）大高建築設計事務所; 静岡市農協センター, 新建築, p. 152, 1971.2

注 14） 長谷川逸子 $\times$ 今野裕一 ; ソフトとハードの間に, p. 115, 1995. 1

注 15) 山本理顕設計工場; プロジェクト 海の家，新建築，p.105，2007.2

注 16) 毛綱礦建築事務所; 丸亀市立城乾小学校, p. 181, 1999.12

注 17) 本稿における統計の性質上，サンプル数が著しく少ないものについて はコレスポンデンス分析の際に扱っていない。よって, 元データの全 てが本稿によって得られた 19 の類型に必ずしも当てはまらないものが ないとは断定できないため,「少なくとも A〜 S の 19 の類型が認めら れた」と表現する。

注 18）リヒアルト・ノイトラ; カルフォルニアのコンクリート住宅，新建築， p. $242,1950.8$

注 19) 佐藤総合計画；今治市火葬場／すいふう苑, p. 124, 2005. 3

注 20) 清水建設一級建築士事務所; 有楽町一丁目ビル, p. 285, 1990.2

注 21) 芦原義信建築設計事務所 ; 浜名湖サービスエリアレストハウス, p. 167, 1969. 4

注 22) 原広司十アトリエファイ建築研究所; ヤマトインターナショナル, p. $148,1987.4$

注 23) 葉デザイン事務所 ; 老人福祉施設三ダイヤル，新建築，p. 200，1996.6

注 24) 石本建築設計事務所 ; 熊本県立自然科学館, p. 212, 1982.6

注 25) 平倉直子建築設計事務所 ; あかり交番 PART 2, p. 191，1997.3

注 26) クラインダイサムアーキテクッ;VERTU GINZA, 新建築, p.129, 2009.5

注 27）玉川地区活性化センター；若松信行＋六本木久志／若松六本木設計, 新建築, p.163, 2000.3

注 28) 丹下健三・都市・建築研究所 ; 渋井邸, 新建築, p.168, 1976.9

注 29) 高松伸建築研究所; 江津市総合市民センター，新建築，p.189，1995.9

注 30) 橿総合計画研究所; 国立国語研究所, 新建築, p.66, 2005.1

注 31) 岩村和男十都市デザイン; 日本老化制御研究所, 新建築, p.224, 1986.1

注 32) KAJIMA DESIGN: 時事通信ビル，新建築，p.86, 2004.1

注 33) 伊藤豊雄建築設計事務所 ; 目黒 T ビル，新建築，p.236，1990.10

注 34) いすバエステート十坂倉築設研究所;CASA BELL OHIRA, 新建築, p.143, 2009.8

注 35) 久米建築事務所 ; ニッセイ総合研究所，新建築，p. $264 ， 1989.6$

注 36) 日建設計 ; 春日尚学ビル, 新建築, p.149, 1999.10

\section{参考文献}

1） J.J. ギブソン著，古崎敬，古崎愛子，辻敬一郎，村瀬旻訳：ギブソン 生 態学的知覚論一ヒトの知覚世界を探る一, サイエンス社, 1985.4

2）北川啓介, 内藤拓也, 寺田享平 : 建築物の言語描写における光の多義性, 日本建築学会計画系論文集，第 680 号, pp.2345-2353,2012.10

3）北川啓介, 米澤隆, 大井亮 : 建築物の言語描写における透明性の多義性, 日本建築学会計画系論文集，第 686 号，pp.791-799,2013.4

4）北川啓介, 米澤隆, 加藤聖仁, 山梨岳美:建築物の言語描写における<間 $>$ の多義性, 日本建築学会計画系論文集, 第 692 号, pp.2119-2126,2012.10

5）徐貴淑：文学作品の空間描写における空間構成の「部分」と「全体」の関 係に関する研究 : 三つの空間構成をケーススタディとして, 日本建築学会 計画系論文集，第 489 号，pp.241-247，1996.11

6) 横山勝樹，高橋鷹志：空間図式の研究：その $1 .<$ 場所>の概念による空 間図式のモデル化，日本建築学会計画系論文報告集，第 395 号，pp.19-30, 1989.1

7) 新建築社 : 新建築, 1950.1-2009.12

8) 三省堂：大辞林，第 3 版，2006.10

9）彰国社 : 建築大辞典, 第 2 版, 2002.6

10）岩波書店 : 広辞苑，第 6 版，2008. 1

11）小学館 : 日本語新辞典, 2005.1

12）三省堂 : 辞林 $21,1993.7$

13）小学館：国語大辞典 言泉，第 1 版，1987. 1

14）新潮社：新潮現代国語辞典, 第 2 版, 2000. 2

15）三省堂：新明解国語辞典，第 6 版，2005.1 